\title{
STUDI KRITIS KONSEP DAN APLIKASI PEMBINAAN MENTAL TNI AD
}

\section{A CRITICAL STUDY OF THE CONCEPT AND APPLICATION OF MENTAL COACHING INDONESIAN ARMY}

\author{
A Ilyas ${ }^{1 a}$ \\ ${ }^{1}$ Fakultas Keguruan dan Ilmu Pendidikan, Universitas Djuanda Bogor, Jl. Tol Ciawi No. 1 Kotak Pos 35 \\ Ciawi Bogor 16720 \\ a Korespondensi: Asmil Ilyas, Email: asmililyas56@gmail.com \\ (Diterima: 30-06-2016; Ditelaah: 30-06-2016; Disetujui: 26-08-2016)
}

\begin{abstract}
The mental construction of Indonesian army is the activity around Indonesian army holding the assignment and obligation to build the mental of soldiers, government employee of soldiers, and their big family its purpose. Is to create moral comparative, solidarity and professionalism of the Indonesian army. To develop the mental construction of Indonesian army has attempted and made various models in developing the best system. In fact, there are still many soldiers (Kodam Jaya) who do the activity which is unsuitable with morality, religion, and nation. Assumption: the main factor is education and Islamic mental construction is still less suitable with the condition and the main problem which is found in the Indonesian army. Because, if someone understand the religion as well, so he will behave politely, far from bad activity, leave the violence and he will not abuse the guidance what he got. The aim of this research is to analyze the basic problem which becomes factors cause less effective of mental construction in Indonesian army especially in the location of research. The result of the research shows that the application of ineffective concept caused by (1) there is less attention of Indonesian army leaders (Kodam Jaya). As it has been known that the character of Indonesian army has high loyalty to the leaders; (2) the material that is given is not suitable with the fact of moral case of Indonesian army especially in Kodam Jaya; (3) the instructor did not follow the curriculum that determined and investigated that matched with the need. Fourth. Learning system just followed the general regulation, unstructured in the short time, place, and the attendance.
\end{abstract}

Keywords: mental construction, moral comparative, professionalism, solidarity.

\begin{abstract}
ABSTRAK
Pembinaan mental TNI AD adalah kegiatan dalam lingkungan TNI AD yang mengemban tugas dan kewajiban untuk membangun mental prajurit, PNS, TNI AD beserta keluarga besarnya. Tujuannya supaya terwujud keunggulan moral, soliditas dan profesionalisme prajurit TNI AD. Untuk mengembangkan pembinaan mental, TNI AD sudah berusaha dan membuat berbagai model dalam rangka mengembangkan sistem yang lebih baik. Namun, masih banyak oknum TNI AD (Kodam Jaya) yang melakukan tindakan yang kurang sesuai dengan moral agama dan negara. Asumsi penyebab utamanya adalah pendidikan dan bina mental rohani Islam masih kurang sesuai dengan keadaan dan akar permasalahan yang ada di TNI AD. Hal tersebut terjadi karena jika seseorang memahami dengan baik dan benar mengenai Islam, maka ia akan dapat berlaku lebih sopan, jauh dari perbuatan munkar, dan menjauhi bentuk kekerasan sampai tindak menyalahgunakan semua amanat yang dia sandang. Tujuan penelitian ialah untuk menganalisis masalah-masalah mendasar yang menjadi penyebab kurang efektifnya pembinaan mental di TNI AD, khususnya Kodam Jaya. Hasil penelitian menunjukkan bahwa aplikasi dari konsep yang tidak efektif disebabkan oleh (1) kurang adanya keterlibatan
\end{abstract}


langsung dari pimpinan dari Kodam Jaya, padahal TNI AD memiliki sifat loyalitas yang tinggi terhadap pemimpin; (2) materi yang diberikan tidak didasarkan pada kenyataan kasus moral TNI AD, khususnya Kodam Jaya; (3) pematerinya tidak mengikuti kurikulum yang sudah ditentukan dan diteliti sesuai dengan kebutuhan; (4) sistem pelajaran hanya mengikuti aturan umum, tidak terstruktur dalam hal waktu, tempat, dan pesertanya.

Kata kunci: keunggulan moral, pembinaan mental, profesionalisme, soliditas.

Ilyas A. 2016. Studi kritis konsep dan aplikasi pembinaan mental TNI AD. Jurnal Sosial Humaniora 7(2): 96-110.

\section{PENDAHULUAN}

Pembinaan mempunyai arti sebuah proses, perbuatan, cara membina, pembaharuan, penyempurnaan usaha, tindakan, dan kegiatan yang dilakukan secara berdayaguna dan berhasil-guna untuk memperoleh hasil yang lebih baik (Depdikbud 1990). Soetopo dan Soemanto (1990) menyatakan bahwa pembinaan adalah menunjuk kepada suatu kegiatan yang mempertahankan dan menyempurnakan sesuatu yang telah ada. Mangunhardjana (1986) mengemukakan bahwa pembinaan sebagai terjemahan dari bahasa Inggris, training yang berarti latihan, pendidikan, dan pembinaan.

Pembinaan mental TNI AD merupakan sebuah kegiatan dalam lingkungan TNI AD yang mengemban tugas dan kewajiban untuk membangun mental Prajurit, PNS TNI AD beserta keluarga besar TNI $\mathrm{AD}$ guna terwujudnya keunggulan moral, soliditas, dan profesionalisme. Fungsi dan peran satuan Bintal TNI AD sebagai pelaksana tugas, selama ini mengalami kemajuan terutama dalam meningkatkan peran Prajurit TNI AD dalam bidang menjadi peran moralitas sebagai pengatur dan petunjuk bagi masyarakat untuk menjadi baik dan tampil sebagai panutan dan mentaati semua aturan hukum, disiplin, dan tata tertib keprajuritan baik tutur kata, sikap, dan tindakan. Meski sudah banyak mengalami kemajuan, pembinaan mental dan kesejarahan yang dilakukan TNI AD masih belum maksimal sebagaimana yang diharapkan (Santoso 2010).

Di sisi lain TNI AD, terutama di bidang Bintal dituntut untuk bersikap kritis dan menyesuaikan diri dengan kebijakan pimpinan TNI AD menghadapi dinamika bangsa dan negara yang terjadi (Zen 2004). TNI AD dituntut pula untuk menampilkan kinerja terbaik dalam mengemban fungsi bintal dan sejarah TNI, bukan malah memperparah keadaan yang sedang terjadi.

TNI juga dituntut untuk berpegang teguh pada jati diri yang telah dimilikinya. Jati diri tersebut merupakan kode etik (pedoman hidup) atau akhlak bagi TNI (Siswosoediro 2009). Pedoman harus dijunjung tinggi dan dilaksanakan bagi setiap prajurit TNI baik dalam kegiatan pribadi maupun organisasi.

Pada umumnya, masyarakat menganggap bahwa TNI sebagai militer yang dilengkapi dengan akal dan senjata cenderung bertindak represif dan opresif dalam memaksakan kehendaknya kepada golongan lain sehingga perlu dijauhkan dari kehidupan politik (Castle 1999). Isu lain yang masih terkait TNI AD adalah watak brutal dan beberapa aspek kehidupan militer. Banyak laporan yang mengungkapkan cara-cara unit-unit militer "melatih" calon tentaranya dengan tujuan untuk menjadikannya instrumen yang patuh. Meskipun salah satu fungsi dari penggemblengan awal ini adalah untuk menjadikan mereka mampu melakukan agresi yang terkontrol dalam pertempuran, terdapat banyak bukti akan terus berlangsungnya kekerasan dari kehidupan militer pada umumnya. Organisasi militer biasanya sangat otoriter, personil yang berpangkat lebih rendah mempunyai resiko mendapatkan perlakuan sewenang-wenang oleh atau mendapat sanksi dan perwira yang lebih tinggi pangkatnya (Shaw 2001). Pada sisi lain, dalam beberapa kasus TNI banyak 
yang melakukan pelanggaran sehingga menyebabkan hukuman pemecatan dan lainlain.

Kenyataan adanya ketimpangan antara tugas TNI yang sangat mulia dengan keberadaan oknum TNI yang melakukan pelanggaran menjadi suatu pertanyaan yang harus dijawab. Salah satu jawabannya adalah dari aspek agama yang mengajarkan bahwa kedamaian, ketenangan jiwa, perbuatan yang baik, dan meninggalkan perbuatan yang buruk adalah hasil yang dicapai ketika seseorang menjalankan perintah agama dengan benar (Suriasumantri 2000).

Kesadaran ini pula yang memberikan suatu kebijakan dalam instansi TNI untuk mengadakan Pembinaan Mental Rohani Islam bagi yang beragama Islam. Secara konseptual, Bintal TNI merupakan salah satu fungsi khusus dalam melaksanakan usaha, pekerjaan, dan kegiatan secara terencana, terarah, dan berlanjut dalam rangka memelihara dan meningkatkan mental prajurit dan PNS berdasarkan agama, Pancasila dan Sapta Marga, Sumpah Prajurit, dan aturan lainnya yang berlaku. Untuk mengembangkannya, TNI sudah berusaha dan membuat berbagai model dalam rangka mengembangkan sistem yang lebih baik. Materi yang diajarkan dalam Bintal Rohani ini berdasarkan keimanan, keislaman, dan keihsanan, serta diberi acuan normatif yang sangat lengkap.

\section{MATERI DAN METODE}

\section{Pendekatan Penelitian}

Pendekatan penelitian menggunakan kajian mengenai fenomena yang terjadi disuatu tempat, yaitu lingkungan TNI Angkatan Darat (Kodam Jaya) yang berkaitan dengan perilaku, persepsi, motivasi, tindakan, dan lain-lain. Objek penelitian yang diteliti adalah perilaku secara fundamental berdasarkan dari hasil pengamatan peneliti sehingga pendekatan yang digunakan berdasarkan penelitian kualitatif (Kirk dan Miller 1986).

\section{Tempat Penelitian}

Penelitian ini dilakukan di Kodam Jaya Jakarta. Kodam Jaya Jakarta berada di Jalan Mayjen Sutoyo Nomor 5, Cililitan, Jakarta Timur.

\section{Sumber Data Penelitian}

Sumber data penelitian adalah sumber data yang terdiri atas kata-kata dan tindakan, sumber tertulis, foto, dan data statistik (Moleong 1997). Sumber data ini cukup signifikan dijadikan rujukan dalam penelitian ini, terutama untuk bahan pembahasan metode pembinaan mental rohani keberagamaan Islam di lingkungan TNI AD.

Sumber data tersebut, dibagi menjadi dua yaitu sumber primer dan sumber data sekunder. Data primer didapat dari kata-kata dan tindakan orang-orang yang diamati atau diwawancarai. Sumber data utama ini dicatat melalui catatan tertulis atau pengambilan foto. Dalam penelitian, peneliti akan menjadi pengamat sekaligus berperan serta pada suatu latar penelitian tertentu. Oleh karena itu, peneliti menjadi sangat beruntung karena akan dapat memanfaatkan sebesarbesarnya suasana dan keadaan faktual yang ada.

Sumber data sekundernya adalah sumber tertulis. Sumber tertulis ini justru menjadi sumber data sekunder yang berfungsi sebagai penguat atas kejadian yang ada dalam lingkup penelitian. Sumber data tertulis terdiri dari sumber buku, majalah ilmiah, sumber dari arsip, dokumen pribadi peneliti selama menjadi TNI, dan dokumen resmi yang ada di lingkungan TNI AD. Sumber buku ini misalnya buku pedoman pelatihan mental, sejarah TNI, sumber latar teoretis mengenai pendidikan dan psikologi yang berkaitan dengan pengembangan sumber daya manusia yang berkualitas, beriman, bertakwa, dan mempunyai kesalehan sosial.

\section{Teknik Pengumpulan Data}

Data yang dikumpulkan adalah data primer yaitu model, bentuk, sistem, dan materi 
pembinaan mental agama Islam bagi anggota TNI Angkatan Darat (AD) yang dilatarbelakangi oleh keberadaan sebagian oknum TNI AD masih ada yang berbuat kurang baik di masyarakat.

Teknik pengumpulan data dilakukan melalui content analysis atau kajian isi (Berger 2000). Konten analisis tidak harus menganalisis teks tertulis, tetapi dapat pula kenyataan yang ada di lapangan.

\section{Teknik Analisis Data}

Proses analisis data dalam penelitian ini dimulai dengan menelaah data yang tersedia yaitu proses bimbingan mental prajurit TNI AD. Prosesnya adalah membaca, pengamatan berperan serta, dan mengumpulkan data. Setelah dibaca, dipelajari, dan ditelaah, maka langkah berikutnya ialah mengadakan reduksi data yang dilakukan dengan jalan membuat abstraksi. Langkah selanjutnya adalah menyusunnya dalam satuan-satuan dalam bab-bab yang sesuai dengan urutan pola berpikir dengan metode dakwah modern.

Untuk membantu, mempermudah, dan memperdalam serta menghilangkan subjektivitas, maka dalam mengkajinya perlu menggunakan pendekatan fenomenologi. Langkah operasional dalam penelitian fenomenologi ini adalah (1) reduksi fenomenologis, (2) reduksi eiditis, dan (3) reduksi transendental.

\section{Reduksi Fenomenologis}

Peneliti menyaring pengalaman agar mendapatkan fenomena yang sebenarnya. Dengan begitu, semua kejadian yang telah terjadi di TNI Angkatan Darat tidak langsung dianggap sebagai kenyataan yang ada, tetapi semua kejadian tersebut perlu dilihat secara heuristik melalui berbagai pandangan, seperti secara psikologis, ekonomi, agama, dan sudut pandang lainnya. Oleh karena itu, semua kejadian tersebut tidak langsung diklaim suatu kebenaran, namun kenyataan yang ada akan diteliti menurut berbagai disiplin ilmu.

\section{Reduksi Eiditis}

Setelah dilihat dari berbagai sudut pandang, maka langkah selanjutnya adalah menentukan dari berbagai gejala yang ada tersebut dalam suatu rangkaian yang paling tepat sehingga pandangan terhadap kenyataan mencapai suatu esensi yang sebenarnya. Sudut pandang ini hanya dikhususkan berkaitan dengan indikasi yang ada dalam temuan di lapangan. Misalnya, mengenai materi bimbingan mental dalam agama Islam, hendaknya juga dilihat segi agama Islam dengan berbagai kerangka teorinya. Misalnya lagi, keterpengaruhan materi terhadap interaksi sosial maka sudut pandangnya adalah psikologi dan sosiologi dan begitu selanjutnya.

\section{Reduksi Transendental}

Langkah ketiga dalam meneliti melalui fenomenologi adalah reduksi transendental. Artinya, semua fakta yang ada di lapangan ini akan dapat dipahami dan dianalisis sesuai dengan kenyataan yang paling faktual, tidak berdasarkan persepsi atau keinginan peneliti. Akan tetapi, berdasarkan kenyataan subjek penelitian itu sendiri (Smith 1995).

\section{Tingkat Keterpercayaan Hasil Penelitian}

Pada penelitian kualitatif, hal yang selalu dipertanyakan adalah tingkat kepercayaan (kredibilitas) terhadap hasil penelitian. Untuk menetapkan keabsahan data tersebut, peneliti telah melakukan teknik pemeriksaan yang didasarkan pada kriteria tertentu yaitu ketekunan pengamatan, triangulasi, pemeriksaan sejawat, dan kecukupan referensial.

\section{HASIL DAN PEMBAHASAN}

\section{Deskripsi Kodam Jaya}

Kodam Jaya lahir dan muncul berkaitan erat dengan sejarahnya peperangan di Indonesia, tepatnya pada tanggal 24 Desember 1949 di Jakarta. Hal itu terjadi setelah penyerahan kekuasaan dari Pemerintah Belanda kepada 
pemerintah Republik Indonesia yang diawali dengan penandatanganan dokumendokumen peralihan kekuasaan atas wilayah Jakarta Raya dari tangan Co Batavia En Ommelanden kepada basis Co Jakarta Raya. Penandatanganan dokumen ini dilakukan oleh Kolonel Vries selaku Basis co Batavia en commelanden mewakili Pemerintah Belanda dan Letkol R. Paswin Nata Diningrat selaku Basis co Jakarta Raya mewakili Pemerintah Republik Indonesia.

Penyerahan kekuasaan inilah yang dijadikan tonggak lahirnya Kodam Jaya (dahulu Kodam V/Jaya). Selain itu, ada beberapa hal penting yang menentukan tanggal 24 Desember 1949 sebagai hari jadi Kodam Jaya yaitu: (1) lahirnya organisasi Basis co Jakarta Raya dan dilengkapi personil pada unsur-unsur Basis Co Jakarta Raya; (2) penandatanganan dokumen-dokumen peralihan kekuasaan atas wilayah Jakarta Raya dan penyerahan badan-badan atau instansi-instansi Militer yang berada di Jakarta Raya dari Baisi Co Batavia en Emmolanden kepada Basis Co Jakarta Raya; (3) pada pertengahan Desember 1949 secara berangsur-angsur mulai berdatangan ke Jakarta seperti Batalyon Kala Hitam dan Batalyon siluman yang memperkuat kedudukan Basis Co Jakarta Raya.

\section{Pembentukan Bintal TNI AD}

Pembinaan rohani agama Islam merupakan salah satu bagian integral di TNI AD dalam mengembangkan mental keprajuritan TNI AD, khususnya Kodam Jaya. Oleh karena itu, pembinaan rohani Islam menjadi salah satu program yang selalu mendapatkan perhatian dari berbagai pihak.

Pimpinan tertinggi di Bintal adalah Kepala Pembinaan Mental Kodam Jaya (Kabintaldam) sebagai eselon pimpinan. Untuk melaksanakan tugas dan tanggungjawabnya, Kabintal dibantu Eselon Pembantu Pimpinan yang terdiri atas Kepala Seksi Metode dan Teknik (Kasimetnik), Kepala Seksi Rohani Islam (Kasirohis), Kepala Seksi Rohani Protestan (Kasirohprot), Kepala Seksi Rohani Katolik (Kasirohkat), Kepala Seksi Rohani Hindu dan
Buddha (Kasirohhinbud), Kepala Seksi Mental ideologi Kepejuangan (Kasitalidjuang), Kepala Seksi Dokumen Penulisan Sejarah dan Pepustakaan (Kasidoklistaka), dan Kepala Seksi Museum, Monumen, dan Tradisi (Kasimusmontra). Selain itu, terdapat pula unsur pelayanan yaitu Kepala Tata Usaha Urusan Dalam (Katuud) dan unsur pelaksana Kepala Badan Pelaksana Pembinaan Mental Juang (Kabalak Bintal Juang).

Pembinaan mental di lingkungan TNI AD memiliki tujuan-tujuan sebagai berikut.

\section{Pembinaan Rohani}

Pembinaan mental TNI AD merupakan upaya ke arah peningkatan mutu prajurit demi terlaksananya tugas pokok TNI AD yang berdaya guna dan berhasil guna, serta meliputi segala usaha, tindakan, dan kegiatan dalam membentuk dan memelihara serta meningkatkan ketahanan mental prajurit terhadap berbagai tantangan dalam hubungan dengan tempat, waktu, dan kondisi berdasarkan Pancasila, Sumpah Prajurit, dan Sapta Marga.

\section{Pembinaan Mental Ideologi}

Pembinaan mental ideologi merupakan pembinaan mental kedua yang diselenggarakan TNI AD. Pembinaan mental ideologi mendapat prioritas dan proporsi yang sama dalam melaksanakannya, selain pembinaan rohani dan pembinaan tradisi kepejuangan. Pembinaan mental ideologi yang terus-menerus dan berlanjut diharapkan mampu menghantarkan prajurit kepada kualitas hidup yang sesuai dengan Pancasila, dan terus-menerus akan menebalkan jiwa kepejuangan yang tinggi, serta menyatukan konsep-konsep atau pandangan yang jelas, tepat, efektif dalam hidup sehari-hari dengan baik.

Metode yang digunakan dalam pembinaan mental ideologi bagi seorang prajurit ialah melalui santiaji dan santikarma. Secara garis besar, kegiatan santiaji antara lain meresapi isi Pancasila, Sapta Marga, dan Sumpah Prajurit, Doktrin Hankamnas dan Perjuangan ABRI/TNI AD, Cadek serta sejarah perjuangan TNI AD. 
Adapun kegiatan santikarma secara garis besar meliputi kegiatan-kegiatan operasi bakti, kegiatan-kegiatan dalam upaya meningkatkan kesejahteraan, dan sekaligus kedisiplinan.

Pelaksanaan pembinaan mental ideologi senantiasa dilaksanakan secara terpadu dan terus-menerus, baik program perorangan maupun kolektif. Hal ini perlu dilakukan agar seorang prajurit di mana pun dan pada situasi apa pun senantiasa teguh dan kuat dalam kepribadiannya.

\section{Pembinaan Tradisi Kepejuangan}

Sejarah tradisi kepejuangan tidak dapat melepaskan diri dari realita masa sekarang dan perspektif masa depan. Tanpa berpijak pada kenyataan hari sekarang dan tanpa memperhitungkan pada kecenderungan yang akan terjadi di hari kemudian, maka sejarah tradisi kepejuangan hanya akan merupakan tujuan masa silam saja yang bersifat statis.

Bertolak dari sejarah militer sebagai sarana pemupukan semangat keprajuritan di atas, maka dalam rangka pembinaan motivasi juang prajurit TNI AD, khususnya pelestarian nilai-nilai juang 1945 dan nilainilai juang TNI 1945, sejarah militer adalah hal yang penting. tujuan pokok pengembangan moril dan jiwa korsa (kehendak) kesatuan berlandaskan nilainilai juang 1945 dan nilai-nilai juang TNI 1945 yang tinggi, yang mana setiap anggota atas dasar kesadaran tersendiri meletakkan kepentingan tugas, tanggung jawab, dan kewajibannya.

Sesuai dengan pentingnya sejarah juang yang mengandung tiga dimensi sekaligus, yaitu masa silam, sekarang, dan yang akan datang, dalam arti bahwa penyelidikan sejarah masa silam tidak dapat melepaskan diri dari realitasnya di waktu sekarang dan dalam perspektif masa depan, maka sejarah TNI AD merupakan faktor yang penting dalam pembinaan motivasi juang prajurit. Lebih-lebih bila dilihat dari fungsi sejarah TNI AD secara aspiratif, yaitu sebagai sarana untuk pembinaan tradisi, semangat juang, sifat kepemimpinan, dan jiwa korsa. Dengan demikian, pembinaan tradisi kepejuangan semacam 'alat kontrol' sekaligus 'obat' yang mujarab bagi prajurit di masa kini dan mendatang. Dengan mempelajari sejarah bangsa, prajurit tidak mengulang tindakantindakan yang negatif dan sebagai obat mujarab prajurit yang tengah berjuang pada zaman sekarang, dihibur, dan diteguhkan keberaniannya, dengan didasarkan kepada motivasi akan meneruskan semangat dan cita-cita para pahlawan atau pejuang yang telah rela berkorban demi kemerdekaan bangsa.

\section{Metode Bintal TNI AD}

Proses pembinaan mental dilakukan dengan cara memberi pengetahuan untuk menambah wawasan prajurit TNI, menumbuhkan motivasi timbulnya perbuatan yang mencerminkan nilai luhur, dan menciptakan kondisi lingkungan yang mendukung. Pada kenyataan kehidupan seorang prajurit TNI adalah prajurit yang berdiri sendiri, pribadi dalam hubungan dengan kesatuan pribadi dalam hubungannya dengan keluarga dan masyarakat lingkungannya. Oleh karena itu, sasaran pembinaan mental prajurit TNI (Mabes TNI 1996) ditujukan pada:

1. prajurit TNI,

2. kesatuan TNI,

3. keluarga besar TNI, dan

4. lingkungan sosial tempat prajurit atau kesatuan berada.

Sementara itu, pembinaan mental TNI dalam rangka membina prajurit yang berpola pada Sapta Marga melalui tiga macam, yaitu (1) pembinaan mental rohani Islam, (2) pembinaan mental ideologi, dan (3) pembinaan mental tradisi kepejuangan.

\section{Pembinaan Mental Rohani Islam}

Pembinaan mental rohani Islam adalah pembinaan mental TNI aspek rohani. Pembinaan mental rohani dilaksanakan melalui pembinaan kehidupan keagamaan sesuai dengan agama yang dianut. Semakin meningkat ketakwaannya kepada Tuhan Yang Maha Esa, maka kualitas prajurit akan meningkat pula sehingga moralitasnya tinggi, memiliki sikap hidup rukun baik 
antarumat beragama maupun umat beragama dengan pemerintah.

\section{Pembinaan Mental Ideologi}

Ideologi yang dimaksud adalah keseluruhan pandangan, cita-cita, nilai, dan keyakinan yang ingin diwujudkan dalam kenyataan hidup bermasyarakat, berbangsa, dan bernegara. Dengan adanya pembinaan mental ideologi kesamaan, keyakinan, dan kebenaran serta kesaktian Pancasila dan UUD 45 akan terpelihara secara mantap.

\section{Pembinaan Mental Tradisi Kepejuangan}

Pembinaan aspek kepejuangan yang bertujuan memupuk dan meningkatkan profesionalisme dan kepejuangan prajurit berdasarkan nilai-nilai luhur yang telah disepakati oleh bangsa Indonesia.

\section{Strategi Pembinaan Mental}

Strategi yang digunakan dalam bintal selama ini adalah (1) persuasif, (2) stimulatif, (3) edukatif, (4) instruktif, (5) simulatif, dan (6) sugestif (Konfidensial Mabes TNI AD 2006). Strategi-strategi tersebut akan dipaparkan lebih jelas sebagai berikut.

1. Persuasif digunakan untuk menumbuhkan kesadaran seluruh anggota dan ikut serta aktif dalam setiap usaha yang dilakukan oleh kesatuan, terutama dengan memberikan tauladan maupun contoh yang baik sesuai dengan nilai, norma baik agama, negara maupun masyarakat.

2. Stimulatif digunakan untuk memberi saran dan pandangan serta nasihat kepada anggota TNI beserta keluarganya agar ikut serta secara aktif dalam setiap usaha pembinaan mental yang diselenggarakan di kesatuan maupun di komplek Kesatriaan TNI AD.

3. Edukatif digunakan untuk mendidik seluruh anggota TNI beserta keluarganya agar ikut serta secara aktif dalam setiap usaha pembinaan mental yang diselenggarakan di kesatuan maupun di komplek Kesatriaan TNI AD.

4. Instruktif digunakan dalam melaksanakan program-program pembinaan, pendidikan maupun

pelaksanaan ceramah-ceramah di lingkungan kesatuan maupun tugas.

5. Simulatif digunakan untuk menanam pengertian dan penghayatan dengan cara memberi pengalaman kepada anggota TNI AD dan keluarganya yang diberikan melalui tiruan keadaan kejadian seharihari dalam masyarakat.

6. Sugestif digunakan untuk memberikan saran-saran dan pandangan kepada para anggota TNI AD beserta keluarganya.

\section{Pemantapan Pembinaan Mental sebagai Fungsi Komando}

Pembinaan mental merupakan salah satu kegiatan dalam rangka fungsi perawatan personil TNI. Perawatan personil merupakan salah satu peran utama dari pembinaan personil TNI yang merupakan salah satu fungsi organik kesatuan TNI. Dengan demikian, pembinaan mental (bintal) merupakan salah satu fungsi komando. Pembinaan mental fungsi komando mengandung dua pengertian yaitu:

1. dalam arti sempit, setiap komando atau pemimpin sesuai dengan lingkup tugas, tanggung jawab dan tingkat komandonya berkewajiban dan bertanggung jawab atas pembinaan mental di kesatuannya;

2. dalam arti luas, setiap atasan atau golongan pangkat yang lebih tinggi atau usia yang lebih tua berkewajiban atau bertanggung jawab atas pembinaan mental dari anggota atau bawahan atau golongan pangkat yang rendah atau yang berusia lebih muda.

Agar tujuan pembinaan mental TNI dapat tercapai secara berhasil dan berdaya guna pelaksanaannya berdasarkan asas-asas sebagai berikut.

1. Asas Kesatuan. Penyelenggaraan pembinaan mental yang dilaksanakan sebagai bagian dari satu kesatuan upaya dalam kegiatan komando.

2. Asas Prioritas. Penyelenggaraan pembinaan mental TNI harus bermanfaat 
baik untuk kekuatan TNI maupun kekuatan pertahanan keamanan negara.

3. Asas Keterpaduan. Penyelenggaraan pembinaan mental harus dapat menentukan mana yang harus dilakukan dan diutamakan baik yang berkaitan dengan kepentingan pembinaan mental maupun kepentingan kesatuan yang lain.

Pada pelaksanaan pembinaan mental TNI fungsi komando, konsep pembinaan berdasarkan pada hal-hal yang pragmatis dan efektif. Pragmatis dalam arti mendasar pada fakta-fakta yang sesuai dengan kenyataan yang nyata sehingga bermanfaat dan dapat segera diterapkan dalam praktik. Efektif dalam arti dapat memberikan pemecahan persoalan yang dihadapi seharihari dengan sebaik-baiknya. Pragmatis dan efektif akan memungkinkan tercapainya hasil yang setinggi-tingginya dan dapat dipertanggungjawabkan penggunaannya.

\section{Penerapan Sistem Kader Pembinaan Mental}

Seorang kader pembinaan mental melaksanakan fungsinya dengan menggunakan peluang yang ada disela-sela tugasnya. Oleh sebab itu, setiap kader pembinaan mental mendapatkan pendidikan dan latihan khusus agar profesional dalam tugasnya. Pengertian kader pembinaan mental (bintal) adalah staf kesatuan yang secara khusus dididik dan dilatih sehingga memenuhi kualitas kader bintal.

Kader pembinaan mental adalah narasumber bagi komandan. Rekan-rekan dan anak buahnya kader pembinaan mental, tetapi mereka akan berfungsi sejauh diperlukan. Guna memenuhi tanggung jawab dan jabatan pokoknya. Pada dasarnya, setiap perwira adalah kader pembinaan mental untuk mewujudkan perlu adanya upaya khusus melalui pendidikan atau penataran pembinaan mental secara berjenjang. Oleh karena itu, komandan bertanggung jawab atas keberhasilan tugas dan fungsi pembinaan mental dalam pembinaan mental bagi kesatuannya.

\section{Pemantapan Kualitas Materi Pembinaan Mental}

\section{Materi Pembinaan}

Materi pembinaan mental yang digunakan pada hakikatnya adalah materi yang mendukung pencapaian tujuan yang telah ditentukan. Pembinaan mental adalah upaya pembinaan sikap yang sesuai dengan nilainilai TNI dalam UUD 45. Oleh karena itu dasar pembinaan mental TNI adalah materi yang mengandung nilai-nilai tersebut dengan segala bentuk perwujudan, penjabaran, dan pengembangan materi tersebut diarahkan untuk memberikan pemahaman pengetahuan yang kemudian akan menimbulkan sikap dan perilaku.

Struktur materi berdasarkan komponen pembinaan mental di lingkungan TNI antara lain:

1. materi pembinaan mental rohani bersumber pada nilai-nilai ajaran agama,

2. materi pembinaan mental ideologi bersumber pada nilai-nilai ideologi negara Indonesia, dan

3. materi pembinaan mental tradisi kepejuangan yang bersumber pada nilainilai budaya dan tradisi keprajuritan bangsa Indonesia.

\section{Kurikulum Pembinaan Mental}

Pada proses pembentukan menjadi seorang prajurit TNI, seseorang yang terpilih akan dididik dan dilatih fisik, intelektual, maupun mentalnya sehingga dianggap memiliki kualifikasi sebagai seorang prajurit TNI. Selanjutnya, setiap perkembangan karir seseorang menentukan kualitas mental yang sesuai. Mengingat perkembangan tersebut dapat terjadi baik penugasan maupun sebagai hasil dari suatu pendidikan, maka kurikulum bintal dalam setiap pendidikan perlu disesuaikan dengan tingkat perkembangan yang ingin dicapai oleh masing-masing pendidikan.

Secara garis besar kurikulum pembinaan mental dalam lembaga pendidikan adalah sebagai berikut. 
1. Pendidikan pembentukan (pendidikan pertama). Tujuan pendidikan bintal pada lembaga pendidikan ini ialah untuk menunjang pembentukan kepribadian sesuai dengan peranan dan golongan pangkat yang bersangkutan. Bobot pendidikan diarahkan untuk pengenalan dan pemahaman tentang pokok-pokok doktrin dan nilai kepejuangan.

2. Pendidikan pengembangan umum dan spesialisasi yaitu:

a. untuk tingkat sarcab. Diklapa II dan Dikbangpers. Bobot pendidikan diarahkan untuk lebih mendalami, menghayati, pokok-pokok doktrin, dan nilai-nilai kepejuangan serta penerapannya di tingkat kesatuan yang akan didudukinya atau untuk menunjang bidang spesialisasinya;

b. untuk tingkat sesko, baik TNI/POLRI maupun sesko TNI dan lemhanas bobot pendidikan diarahkan pada pengkajian pokok-pokok doktrin dan nilai-nilai kepejuangan serta perumusan konsepsi pengembangan dan penerapannya di kesatuan.

\section{Pendidikan Non Formal}

Kurikulum pendidikan non formal bertujuan untuk meningkatkan dan memantapkan kemampuan prajurit sesuai dengan tuntutan tugasnya searah dengan tujuan searah. Dengan tujuan tersebut, bobot pendidikan diarahkan untuk meningkatkan dan memantapkan penerapan bintal sesuai bidang tugasnya.

\section{Tata Cara Pembinaan Mental}

Santiaji atau santikarma (aji karma) merupakan salah satu komponen dalam pembinaan mental TNI yang dapat dimiliki dengan ketenangan batin melalui pemberian dan pengalaman ilmu. Santiaji atau santikarma sebagai salah satu metode pembinaan mental TNI merupakan tata cara yang ditempuh untuk memberikan dan mengamalkan ilmu agar prajurit TNI memiliki ketenangan batin sehingga mampu memecahkan masalah yang dihadapi dengan penuh kesadaran dan keyakinan. Dengan kata lain, berarti pula dapat melaksanakan setiap tugas yang dibebankan dengan sebaikbaiknya.

Metode santiaji adalah cara-cara yang ditempuh untuk memberi ilmu pengetahuan agar prajurit TNI memiliki ketenangan lahir batin. Dalam metode santiaji telah diutamakan usaha-usaha meyakinkan kesempatan yang seluas-luasnya untuk berdialog dan berkomunikasi antara yang memberi santyang menerima santiaji. Metode santiaji dapat dilaksanakan dengan ceramah, tanya jawab, diskusi, kerja kelompok, sosiodrama, dan karya wisata. Metode karma adalah cara-cara yang ditempuh untuk memberikan kesadaran ilmu pengetahuan yang dimilikinya kepada lingkungan.

\section{Analisis dan Solusi Atas Pembinaan Mental Rohani Islam}

\section{Konsep Pembinaan Mental}

Konsep yang selama ini dimiliki, secara spesifik belum dapat dilaksanakan dengan baik oleh Kodam Jaya. Indikasinya adalah masih banyak oknum dari TNI AD dalam hal ini Kodam Jaya yang melakukan pelanggaran moral, etika, dan pelanggaran lainnya yang menyimpang dari fungsi dan tujuan bintal itu sendiri. Konsep yang sudah menjadi petunjuk pelaksanaan TNI AD juga mengalami dilema. Salah satu penyebabnya adalah tidak ada kesesuaian antara kenyataan yang dialami anggota TNI AD dan petunjuk dari institusi tersebut.

Salah satu masalah yang sering terjadi terutama dalam bidang pembinaan mental rohani Islam adalah mengenai penguatan akidah dan akhlak yang dapat mempengaruhi proses setiap tindakan seluruh anggota TNI AD dan keluarganya. Akan tetapi, justru yang muncul dalam hal juklak adalah masalah fikih, sedangkan masalah akidah dan akhlak hanya sedikit persinya. Selain itu, akidah dan akhlak hanya diajarkan secara normatif tanpa ada perubahan yang sesuai dengan tingkat 
kecerdasan dan kedewasaan anggota TNI itu sendiri.

Oleh karena itu, TNI AD memerlukan pembaharuan dalam memikirkan dan mengajarkan akidah yaitu dengan cara memikirkan keagamaan yang merefleksikan respons manusia terhadap wahyu Allah swt (Rahardjo 1983). TNI AD juga memerlukan akidah bukan sekedar sebagai sebuah ajaran abstrak tentang ketuhanan, akan tapi akidah sebagai penafsiran terhadap realitas dalam perspektif ketuhanan dan merupakan refleksi-refleksi empiris yakni akidah yang diajarkan adalah refleksi praktikal dari ajaran-ajaran tauhid dalam kehidupan (Kuntowijoyo 1991). Akidah atau teologi seperti ini biasa dikenal dengan teologi transformatif yang melihat Islam sebagai ideologi liberatif dan emansipatoris dalam pengertian kongkrit (Anwar 1995). Pada akidah ini, tauhid merupakan ide sentral yang mempunyai konsekuensi praksis pemihakan TNI AD terhadap proses menuju persamaan derajat di antara sesama manusia. Teologi seperti ini memberikan suatu ide bahwa pelapisan sosial, kelas-kelas sosial, dan kesenjangan merupakan realitas yang tidak tauhidi.

Sementara itu, masalah metode bimbingan mental bagi prajurit TNI, selama ini yang ditekankan hanya berupa penggunaan metode mau'idzah hasanah melalui kegiatan ceramah vokasional atau oral pada pengajian, istigasah, yasinan, tahlilan, dan peringatan hari besar Islam. Metode ini sudah tidak dapat dijadikan sebagai satu-satunya metode dalam menyampaikan bintal di kalangan TNI AD dan tidak sesuai dengan metode santiaji yang telah dicanangkan.

Kenyataan yang di atas tentu saja telah memaksa Bintal TNI AD sebagai bagian pengajaran atas ajaran Islam dan membentuk karakter muslim sejati harus berpikir ulang tentang masa depan kehidupan Bintal Rohani Islam, terutama yang berkaitan langsung dengan aspek dakwah yang merupakan 'denyut nadi' dari bimbingan Rohani Islam itu sendiri. Pertanyaannya, adalah "Apakah konsep dakwah Binrohis TNI AD selama ini mampu melawan atau paling tidak mengimbangi kemajuan zaman, atau malah disebabkan ketidakmampuan untuk menyeimbangkan kemajuan ini yang menyebabkan dakwah Binrohis TNI AD hampir dapat disebut tidak memberi makna sama sekali bagi kehidupan?" Jika demikian, tentu saja ada yang bermasalah dalam teknis pelaksanaan, kurikulum atau materi Binrohis TNI AD, atau para pemateri Binrohis TNI AD alpa untuk melaksanakan tugasnya?

Pada kaitan ini, nampaknya justru teknis pelaksanaan pendidikan Binrohis TNI AD yang bermasalah sebab ada kecenderungan dalam pelaksanaan pendidikan Binrohis TNI AD masih dilakukan secara tradisional, yaitu hanya terikat pada pemaknaan oral semata. Salah satu masalah yang ada adalah rendahnya aktualisasi diri Binrohis TNI AD, terutama para pemateri dakwah itu sendiri terhadap kemajuan teknologi, materi yang kurang mempunyai kesinambungan antara satu tema dengan tema yang lain dan berkaitan dengan jumlah dan waktu serta model yang tidak terukur dan terstruktur dengan baik.

Berdasarkan pengamatan peneliti, sebenarnya Binrohis TNI AD telah berupaya untuk mengembangkan pendidikan dengan mengikuti kemajuan teknologi. Permasalahannya adalah para pemateri yang melaksanakan tugas di TNI AD belum siap untuk berhadapan dengan teknologi tersebut. Ketika ada dakwah dalam wujud teknologi, justru yang terjadi lebih menonjol tampilan formalisnya saja dan cenderung kehilangan makna terdalam dari pendidikan yang sesungguhnya dan masih banyak permasalahan lain. Oleh karena itu, untuk mempermudah dalam menganalisis permasalahan yang ada dalam konsep pembinaan mental TNI AD ini akan dilihat dari dua sisi yang berkaitan yaitu masalah hardware dan software Bintalad.

\section{Hardware Bintalad}

Hardware yang dimaksud adalah perangkat keras yaitu berupa kepemimpinan, personel 
yang mengikuti Bintal, dan media pelaksanaan Bintal.

Kewajiban para komandan satuan di Bintal adalah memberdayakan lembaga Bintal yang ada di satuan dengan cara: (1) dalam hal personil, bagi satuan yang ada Pabintalnya agar memberdayakan secara optimal, sedangkan yang tidak ada agar bersandar pada Komando atas atau Satuan samping atau tetangga; (2) dalam kerja sama pemanfatan penceramah atau guru agama dari luar TNI hendaknya dilakukan secara selektif agar tidak terjadi kesalahan.

Selanjutnya, pada saat ini, masyarakat dunia dalam era globalisasi dan era reformasi terdapat tantangan tugas yang semakin berat, cepat, dan kompleks, serta menuntut sikap transparansi, kejujuran, dan kemitraan yang menjunjung nilai-nilai hukum, hak asasi manusia, dan demokratisasi. Tuntunan yang demikian menjadikan sikap dan perilaku serta tindakan prajurit harus disesuaikan dengan perkembangan yang sedang terjadi agar berbagai citra negatif dari penampilan prajurit pada masa lalu dapat diperbaiki sehingga masyarakat tetap simpati dan kemanunggalan TNI dengan rakyat tetap lestari.

Di era globalisasi ini, maka yang menjadi salah satu tugas Bintal Rohani Islam adalah membentuk prajurit yang kreatif dan produktif yaitu menjadi tentara yang menjadi daya manusia yang tidak sekedar sebagai penerima arus informas. Akan tetapi, harus memberikan bekal kepada mereka agar dapat mengolah, menyesuaikan, dan mengembangkan segala hal yang diterima melalui arus informasi itu.

Sebagai bentuk dari hasil tentara yang produktif, maka TNI yang mendapatkan pendidikan di Binroh secara hardware harus mempunyai beberapa hal antara lain: kesatu, menerima dirinya secara ikhlas dengan segenap kelebihan dan kekurangannya. Dia tidak membuang-buang waktu untuk menikmati kelebihan yang ada pada dirinya atau menyesali kekurangan. Dia tidak lebih banyak menggunakan waktunya untuk memikirkan apa yang dapat dilakukan dengan segenap sifat yang ada pada dirinya, segenap pengetahuan yang dimilikinya, betapa pun terbatasnya pengetahuan itu dan segenap ketrampilan yang dimiliki.

Kedua, menerima lingkungan hidupnya secara ikhlas. TNI yang produktif adalah TNI yang tidak menyesali dirinya bahwa ia dilahirkan, berada di lingkungan dan di sebuah institusi atau negara dengan berbagai tugas yang dimiliki. Ia mampu bersifat realistik dalam menjalani hidup dan tugas sebagai TNI dan tidak berusaha untuk berbuat yang tidak baik yang melampui tugas utamanya sebagai TNI

Ketiga, peka terhadap kebutuhan zamannya. Tanpa kepekaan terhadap kebutuhan lingkungannya, maka TNI tidak dapat bermanfaat atas kebutuhan lingkungannya. Akibatnya, keberadaannya kurang memberi manfaat bagi lingkungannya atau malah memberi mudarat bagi masyarakat sekitarnya. Oleh karena itu, TNI juga harus mendapatkan pelajaran akhlak dengan baik dan terpadu sehingga kepekaan terhadap lingkungan menjadi kuat dan dapat memberi dampak positif bagi lingkungan ketika ia tinggal.

Keempat, merasa mampu bekerja atau berkarya dan merasa mengenal serta menguasai metode-metode kerja yang terdapat dalam berbagai bidang garapannya. Tanpa suatu kepercayaan, orang tidak mampu produktif. Namun demikian, suatu hal yang tidak boleh dilupakan bahwa produktivitas adalah fungsi kerja dan sifat produktif adalah manifestasi dari dorongan kerja yang ada dalam diri seseorang (Buchari 1994).

\section{Software Bintalad}

Software bintalad adalah dalam tataran konsep atau materi. Selama ini konsep bintal rohani Islam masih dikonsepsikan sebagai pembahasan tentang Pendidikan Agama Islam (PAI) yang seringkali dikaitkan dan disamakan dengan Pendidikan Islam, baik secara etimologi maupun terminologi. Sebagian prajurit TNI AD di Kodam Jaya 
memahami bahwa antara pendidikan Islam dan pendidikan agama Islam memiliki arti dan makna sama. Bahkan, bagi mayoritas prajurit TNI AD di Kodam Jaya pendidikan Islam lebih banyak dipahami sebagaimana halnya bagian dari mata pelajaran di sekolah-sekolah formal, yang secara formal diberikan kepada seluruh siswa dari sekolah tingkat dasar sampai perguruan tinggi yang beragama Islam.

Seharusnya, konsep bimbingan Rohani Islam di Bintal TNI AD tidak saja hanya mengenalkan Islam sebagaimana Pendidikan Agama Islam (Suprayogo 2010), tetapi sebagai konsep Pendidikan Islam. Pendidikan Islam memiliki makna dan filosofi lebih luas dibandingkan Pendidikan Agama Islam. Pendidikan Islam sebagai sistem pendidikan Islami yang memiliki komponen-komponen untuk mendukung terwujudnya sosok muslim ideal yang teorinya didasarkan pada Al-Qur'an dan Hadis.

Untuk mencapai hasil yang maksimal, penerapan konsep kurikulum Binrohis Bintal TNI AD dapat diterapkan melalui dua model pendekatan, yaitu pendekatan makro dan pendekatan mikro. Kedua pendekatan tersebut digunakan untuk mengefektifkan penerapan kurikulum Pendidikan Agama Islam yang memiliki jangkauan visi yang luas dan terpadu (integral) berdasarkan kebutuhan dan orientasi pembelajaran Pendidikan Agama Islam yang memiliki nuansa futuristik dan penuh dengan harapan dari semua pihak, terutama prajurit TNI AD.

\section{Pendekatan Makro}

Model pendekatan makro berupaya menghadirkan proses pembelajaran Pendidikan Agama Islam bagi seluruh komponen TNI-AD agar dapat memberikan nuansa yang berbeda dan harapan kolektif dari semua pihak, baik oleh kalangan militer, birokrat, sipil atau masyarakat. Adapun langkah-langkah yang harus ditempuh yaitu: (1) merancang program pembelajaran yang unggul; (2) merumuskan kembali tujuan kurikulum Binrohis; (3) menciptakan sumber belajar unggul.

\section{Pendekaran Mikro}

Model pendekatan mikro dalam reformulasi penerapan kurikulum pembinaan mental rohani Islam yaitu suatu tahapan secara praktis dan sistematis yang memperhatikan situasi dan kondisi sumber daya dukung lembaga pembinaan mental. Melalui pendekatan mikro ini, penerapan kurikulum pembinaan mental Rohani Islam di lingkungan TNI AD dapat tercapai secara terukur dan dapat berhasil secara maksimal.

Pendekatan mikro lebih dihadapkan pada hal-hal yang bersifat fungsional, khususnya pengembangan materi, peran guru, dan para prajurit TNI AD dalam interaksi pembelajaran. Ketiga komponen tersebut merupakan suatu sistem dalam pendidikan yang perlu mendapatkan perhatian oleh para pelaku pendidikan. Adapun langkah-langkah yang dapat ditempuh lembaga pendidikan untuk menerapkan kurikulum Pendidikan Agama Islam melalui model pendekatan mikro ini antara lain:

1. menentukan tujuan materi;

2. mengukur kemampuan awal para prajurit dan solusinya;

3. pembentukan perfomansi (perilaku);

4. menyusun evaluasi.

\section{Aplikasi Pembinaan Mental TNI AD}

Berdasarkan penelitian yang telah dilaksanakan dan pemaparan data-data yang diperoleh, maka temuan-temuan yang diperoleh terkait dengan pelaksanaan Bimbingan Mental pada Sibinrohis TNI AD adalah hendaknya konsep dan aplikasi pembinaan mental rohani Islam secara transformarif dan metode yang bervariatif tidak sekedar oral atau vokasional bagi tiap individu prajurit TNI AD.

Gagasan bimbingan Mental TNI AD (Binrohis) berparadigma transformatif merupakan salah satu corak paham keislaman bagi prajurit TNI AD yang muncul sebagai respons terhadap keberadaan ajaran Islam yang diajarkan seolah-olah kurang terlibat dalam menjawab berbagai masalah yang aktual. Islam yang diajarkan dalam bimbingan mental TNI AD terkesan hanya 
digunakan sebagai legitimasi terhadap kesalehan individual prajurit TNI AD dan tidak diwujudkan dalam konteks kesalehan sosial prajurit TNI AD. Dalam hubungan ini, Islam hanya digunakan sebatas urusan hubungan seorang prajurit TNI AD dengan Tuhan, dan tidak terlibat dalam urusan hubungan prajurit TNI AD dengan alam, lingkungan sosial, dan berbagai problema kehidupan yang semakin kompleks dan penuh tantangan.

Oleh sebab itu, pembinaan mental TNI AD perlu menumbuhkan sikap beragama yang kritis-transformatif menjadikan landasan tauhid sebagai spirit pergerakan bela negara dan menyuarakan perlawanan terhadap segala bentuk tirani dan ketidakadilan, kesewenang-wenangan dan kemungkaran sebagai pemaknaan kreatif terhadap fungsi kehadiran manusia sebagai khalifah. Tujuan liberasi (tanhauna 'anil mungkar) adalah pembebasan dari kekejaman kemiskinan struktural, eksploitasi, keangkuhan teknologi, pemerasan kelimpahan dan ketidakadilan distribusi.

\section{Alternatif Materi Bintal Rohani}

Jika dilihat dari sistem yang telah digunakan dalam pembinaan mental keberagamaan yang dilaksanakan di TNI AD, maka akan nampak ketidaksesuaian antara materi yang selama ini diberikan dengan kenyataan yang ada di lapangan. Kenyataan yang ada ialah ada beberapa anggota TNI yang berbuat kurang baik dalam bermasyarakat, seperti menjadi penadah, perampok, berbuat zina, dan sebagainya, yang seharusnya sudah diantisipasi sejak awal. Antisipasi yang ada adalah memberikan pelajaran dalam pembinaan mental keagamaan prajurit melalui pendidikan akidah dan akhlak secara komprehensif dan koheren, bukan menekankan pada aspek ritual fikih yang mendalam.

Aspek ritual fikih memang perlu untuk dilaksanakan secara baik, tetapi bukan segalanya dalam mengajarkan di Bintal. Aspek fikih yang harus diajarkan cukup mengenai hal-hal yang ditemukan ketika berada di lapangan seperti salat Khauf, salat
Jamak, puasa, dan lain-lain. Sementara itu, aspek lain seperti zakat, haji, nikah, jual beli, dan lain-lain cukup menjadi kajian para prajurit di luar Bintal. Adapun aspek yang harus ditekankan dalam Bintal adalah yang berkaitan dengan akidah dan akhlak dengan menekankan aspek kritis dan menggunakan nalar yang kuat bukan sebagai doktriner. Hal ini berbeda jika digunakan untuk Bintal kepejuangan dan ideologi yang memang harus menggunakan model doktriner.

\section{KESIMPULAN DAN IMPLIKASI}

Sebelum mengadakan penelitian lebih dalam, maka dilakukan penelitian secara kuantitatif mengenai pengaruh Bintal dalam kehidupan mereka. Berdasarkan kuesiner yang disebarkan kepada anggota TNI AD di Kodam Jaya, sebanyak 300 personel, maka hasil pengumpulan datanya adalah 11730. Dengan demikian, pengaruh pembinaan mental rohani Islam di Kodam Jaya TNI AD, menurut persepsi 98 responden, yaitu $11730 / 19600$ X 100\%= 59,8469387755102 $=60 \%$.

Nilai 60 \% dapat diinterpretasikan dalam nilai cukup dan nilai 11730 termasuk dalam kategori cukup. Artinya, masih perlu banyak perbaikan dalam bintal rohani Islam sehingga mempunyai efek positif dalam membinan keagaman para prajurit.

Selanjutnya, berdasarkan penelitian yang telah dibatasi dan dirumuskan sebelumnya, maka dapat disimpulkan dalam beberapa hal sebagai berikut.

1. Konsep pembinaan rohani agama Islam pada Bintal TNI AD, khususnya Kodam Jaya digunakan sebagai bentuk pembinaan, kegiatan dalam bentuk bimbingan, penyuluhan, dan pelayanan. Konsep-konsep tersebut dilaksanakan dalam rangka membina, meningkatkan keimanan dan ketakwaan, mempertinggi budi pekerti, akhlak luhur, dan memberi pelayanan keagamaan bagi prajurit dan PNS AD beserta keluarganya di lingkungan Mabes TNI AD khususnya Kodam Jaya Jakarta. Konsep yang sudah 
memuat mengenai tujuan, fungsi, kurikulum, metode, dan sebagainya belum dapat diaplikasikan dengan baik. Hal ini diindikasikan dengan adanya tindakan amoral dari oknum TNI AD Kodam Jaya.

2. Aplikasi dari konsep yang tidak dapat efektif ini disebabkan oleh pucuk pimpinan dari Kodam Jaya itu sendiri, yaitu ketidakteladanan sebagaimana dalam konsep santi karma TNI atau dalam ajaran Islam. Misalnya, ketidakikutsertaan pimpinan dalam Binroh. Sebagaimana yang telah diketahui bersama, sifat TNI AD khususnya Kodam Jaya loyalitas yang tinggi terhadap pemimpin. Kasus yang lainnya adalah ketika ada Binroh, pimpinan meminta salah satu peserta untuk mengikuti kegiatan lain yang waktunya sama dengan Binroh.

3. Materi yang diberikan sebenarnya sudah mempunyai kurikulum dan isi yang mapan, tetapi belum terencana sesuai dengan teori pendidikan sehingga antara input, output, dan outlook tidak ada. Pada sisi lain, materi yang diberikan tidak didasarkan pada kenyataan kasus moral TNI AD khususnya Kodam Jaya yang ada di lapangan. Jadi, konsep yang sudah dibangun dan dikuatkan oleh beberapa kebijakan secara lokal dari pimpinan belum menjawab kebutuhan TNI AD khususnya Kodam Jaya di masyarakat.

4. Oleh karena itu, perlu ada solusi konsep yang sudah ada. Misalnya, mengenai materi sebaiknya yang disampaikan adalah mengenai akidah dan akhlak yang diajarkan secara kritis dengan menunjukkan beberapa indikasi, bukan dijadikan sebagai doktrin yang harus diikuti. Hal ini berkaitan dengan tingkat kedewasaan para anggota TNI. Bintal rohani harus dibedakan dengan Bintal ideologi yang berlaku dalam TNI.

5. Pemateri harus mengikuti kurikulum yang sudah ditentukan dan diteliti sesuai dengan kebutuhan. Pada sisi lain, pemateri harus menggunakan beberapa metode yang menarik. Sistem pelajaran yang selama ini hanya umum hendaknya dirubah menjadi terstruktur dalam hal waktu, tempat, dan pesertanya. Hal ini dapat meningkatkan kepemahaman bagi anggota TNI. Selain itu, semua anggota dapat mengikutinya secara kontinyu tanpa harus diganggu oleh kegiatan lain yang tidak mendesak.

\section{DAFTAR PUSTAKA}

Anwar MS. 1995. Pemikiran dan aksi Islam di Indonesia, sebuah kajian politik tentang cendekiawan muslim orde baru. Paramadina, Jakarta.

Berger AA. 2000. Media and communication research methods; an introduction to qualitative and quantitative approaches. Sage Publications, London.

Buchari M. 1994. Ilmu pendidikan dan praktik pendidikan. IKIP Muhammadiyah Jakarta Press, Jakarta.

Castle L. 1999. ABRI dan kekerasan. Pustaka Pelajar, Yogyakarta.

Depdikbud. 1990. Kamus Besar Bahasa Indonesia. Balai Pustaka, Jakarta.

Kirk J dan ML Miller. 1986. Reliability and validity in qualitative research. Sage Publications, Beverly Hills.

Konfidensial Mabes TNI AD. 2006. Buku petunjuk pelaksanaan pembinaan mental ideologi personel TNI AD. Pers 003.004, Publikasi Umum TNI AD.

Kuntowijoyo. 1991. Paradigma Islam: interpretasi untuk aksi. Mizan, Bandung.

Mabes TNI 1996. Pusat pembinaan mental, Dharma Ksatria Sapta Marga. Suspa Bintal TNI, Jakarta.

Mangunhardjana. 1986. Pembinaan arti dan metodenya. Kanisius, Yogyakarta.

Moleong LJ. 1997. Metodologi penelitian kualitatif. Remaja Rosdakarya, Bandung.

Rahardjo D. 1983. Umat Islam dan pembaruan teologi. Lappenas, Jakarta.

Santoso I. 2010. Peningkatan kualitas mental prajurit dan keluarganya dalam mendukung tugas pokok TNI AD. Kodam I Bukit Barisan, Medan.

Shaw M. 2001. Bebas dari militer (analisis sosiologis atas kecenderungan 
masyarakat modern). Pustaka Pelajar, Yogyakarta.

Siswosoediro HS. 2009. Buku pintar calon anggota dan anggota TNI. Visimedia, Jakarta.

Smith B (ed). 1995. The Cambridge Companion to Husserl. Cambridge University Press, Melbourne.

Soetopo H dan W Soemanto. 1982. Pembinaan dan pengembangan kurikulum. Bina Aksara, Jakarta.
Suprayogo I. 2010. Peta pendidikan Islam di Indonesia. Makalah sebagai bahan Semiloka di Majlis Ulama Indonesia (MUI) Pusat, Jakarta.

Suriasumantri JS. 2000. Filsafat ilmu: sebuah pengantar populer. Pustaka Sinar Harapan, Jakarta.

Zen K. 2004. Konflik dan integritas TNI AD. Institute for Policy Studies, Jakarta. 